\title{
A Report of Acute Thoracic Epidural Hematoma after Interlaminar EPIDURAL INJECTION
}

\author{
John R. Swicegood, MD¹, Laxmaiah Manchikanti, MD², Ramsin M. Benyamin, MD ${ }^{3}$, and \\ Joshua A. Hirsch, MD ${ }^{4}$
}

While interlaminar and caudal epidural injections are frequently performed for chronic spinal pain, thoracic epidural injections are uncommon; constituting less than $5 \%$. As a result, reports of complications related to thoracic epidural injections are rare including epidural hematoma leading to surgical decompression. Multiple strategies to prevent epidural hematoma in any region of the spine exist and include cessation of therapy with antithrombotics and anticoagulants, fish oil, and other drugs with a potential effect on coagulation. Thus far, multiple guidelines have recommended continuation of nonsteroidal antiinflammatory drugs (NSAIDs) and low dose aspirin. Some guidelines also have recommended continuation of antithrombotic therapy because of the increased risk of thromboembolic phenomenon in these patients.

We report a case of thoracic epidural hematoma requiring surgical decompression without resultant residual dysfunction. It involves a thoracic epidural injection following which the patient developed left leg paresis over a 2-hour postinjection period. She was receiving low dose (81 $\mathrm{mg}$ ) aspirin. She underwent surgical decompression with rapid recovery.

This case report of acute thoracic epidural hematoma following interlaminar epidural steroid injection in a patient without antithrombotic therapy is rare, that could have been fatal without appropriate diagnosis and intervention. This case report shows that various commonly considered factors and precautions undertaken to avoid epidural hematoma formation are ineffective. This case report also illustrates the importance of prompt diagnosis, and emphasizes increasing levels of axial pain as most significant features for the diagnosis.

Key words: Interventional techniques, thoracic epidural injections, thoracic epidural hematoma, bleeding disorders, aspirin, antithrombotic agents, anticoagulants, nonsteroidal antiinflammatory drugs
From : ${ }^{1}$ Advanced Interventional Pain and Diagnostics of Western Arkansas, Fort Smith, AR; ${ }^{2}$ Pain Management Center of Paducah, Paducah, $\mathrm{KY}$, and University of Louisville, Louisville, KY; ${ }^{3}$ Millennium Pain Center, Bloomington, IL, and University of Illinois, Urbana-Champaign, IL; ${ }^{4}$ Massachusetts General Hospital and Harvard Medical School, Boston, MA

Author for correspondence: Laxmaiah Manchikanti, MD Address: Pain Management Center of Paducah, 2831 Lone Oak Rd, Paducah, KY 42003

E-mail: drlm@thepainmd.com
Epidural injections with or without steroids are commonly performed procedures used in the management of chronic pain in the lumbar and cervical spine and occasionally in thoracic spine (1-3). The present utilization data in the United States in the Medicare population showed an overall increase in epidural injections of $99 \%$ per 100,000 Medicare beneficiaries from 2000 to 2014 (2). While lumbosacral interlaminar and caudal epidural injections decreased $2 \%$ per 100,000 Medicare beneficiaries, cervical and thoracic interlaminar epidural injections increased $104 \%$ per 100,000 beneficiaries. Among these procedures, thoracic epidural injections are the least commonly performed procedures. Manchikanti et al (3), in an assessment of a total of 10,261 epidural injections 
showed only 301 performed in thoracic spine with interlaminar approach (3). Further, there is very little literature assessing the role of thoracic epidural injections (4-6). Consequently, it is expected that complications related to thoracic epidural injections are infrequent, specifically with formation of acute epidural hematoma after the procedures performed for chronic pain management. In fact, there have been only 2 published reports of thoracic epidural hematoma and related complications following epidural steroid injections $(7,8)$. However, there are multiple reports of epidural hematoma in patients with paravertebral catheters $(9,10)$ spontaneously without trauma (11-15), after shockwave lithotripsy (16), after spinal manipulative therapy (17), minor trauma (18), and spinal cord lead placement (19-24). Further, there have been multiple reports of cervical epidural hematomas following epidural injections for chronic pain with some reports from lumbar interlaminar epidural injections (25-30).

The literature has no prevalence statistics for thoracic epidural hematoma; however, a rate of 1.38 in 10,000 to 1 in 250,000 epidural procedures has been reported for the cervical region (31). Manchikanti et al (28) reported a prevalence of $0.085 \%$ with 2 cases of epidural hematoma in 23,523 cervical epidural injections performed from 2000 to 2015. Multiple authors (32-35) have studied issues related to bleeding complications in interventional pain management.

At present, national and international guidelines recommend continuation of nonsteroidal antiinflammatory drugs (NSAIDs) and low dose aspirin therapy (36-38), even though there are continued discussions and debate in reference to the cessation of prophylactic antithrombotic therapy.

We report a single case of thoracic epidural hematoma in a patient on $81 \mathrm{mg}$ daily dose of aspirin.

\section{CASE REPORT}

This case report of acute thoracic epidural hematoma involves a female patient undergoing thoracic epidural injection in December 2010 by an experienced interventional pain physician. She was referred for management of thoracic pain with no anticoagulant therapy; but she was receiving $81 \mathrm{mg}$ of aspirin. Thoracic epidural injection under fluoroscopic guidance was performed at T10-T11. After appropriate monitor- ing in the recovery room she was discharged in satisfactory condition. She reported left leg paresis 2 hours after the procedure. Immediately she was admitted to the hospital and computed tomography (CT) was performed. The findings of the CT were consistent with epidural air and hematoma in the lower thoracic spine, beginning at approximately the T9-10 disc space level and extending inferiorly into the upper aspect of $L 1$, at the T12-L1 disc space as shown in Fig. 1 with sagittal reconstruction. Axial images are shown in Fig. 2. There was significant narrowing of the spinal canal. Neurosurgery performed decompression with thoracic and lumbar laminectomy resulting in rapid recovery from the effects of the epidural hematoma and improvement in her thoracic pain.

\section{DISCUSSION}

This appears to be the third case of acute epidural hematoma following epidural steroid injections in managing chronic spinal pain $(7,8)$. The patient developed a thoracic epidural hematoma and required surgical intervention for decompression. The patient was on low dose aspirin therapy. There was no antithrombotic or anticoagulant therapy. The patient recovered without any residual dysfunction. Overall, while the literature is filled with multiple case reports of cervical epidural hematoma in chronic spinal pain patients, there is a paucity of literature not only about the complications of thoracic epidural steroid injections, but also about its effectiveness and specifically epidural hematoma formation (3-24). As reported earlier, there have been 2 case reports of thoracic epidural hematoma related to epidural injections.

While epidural hematoma in chronic spinal pain management is of major concern, cessation of antithrombotic therapy or anticoagulant therapy may result in significant morbidity and mortality with thromboembolic phenomenon. Cardiovascular disease is the leading cause of death globally and in the United States, with a death every 43 seconds in the United States contributing to over 375,000 deaths per year (32). Consequently, many patients on various types of antithrombotic or anticoagulant drugs suffer with chronic pain and receive epidural injections as a treatment modality. A prospective evaluation of practice patterns of perioperative management of antiplatelet and anticoagulant therapy in interventional pain 

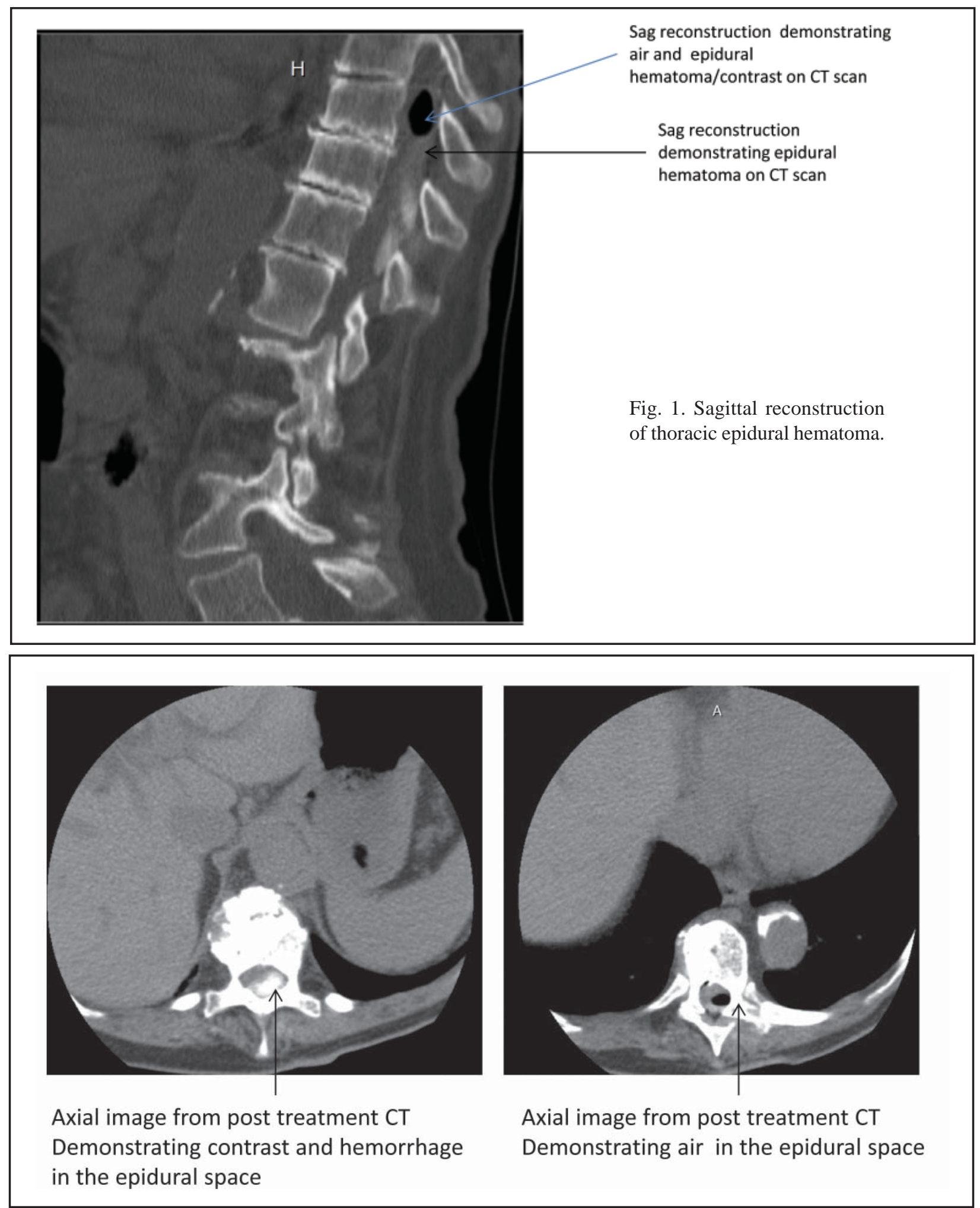

Fig. 2. Axial images of thoracic epidural hematoma. 
management (33) showed serious complications of thrombotic events 3 times more frequently than bleeding complications from epidural hematomas (162 versus 55). Not surprisingly, this assessment also showed similar bleeding complications with epidural hematomas with or without cessation of antithrombotic therapy. There are no case reports at the present time of acute epidural hematoma in patients with continuation of prophylactic antithrombotic therapy. In a prospective assessment, Manchikanti et al (34) reported no occurrence of epidural hematoma in patients with or without cessation of antithrombotic therapy. Similarly, Endres et al (35), in assessing the risks of continuing or discontinuing anticoagulants for patients undergoing common interventional pain procedures, have concluded that discontinuation was associated with a low risk of $0.2 \%$, even though the risk of serious complications was not zero. However, in this study they did not performed any thoracic interlaminar epidural injections.

Apart from antithrombotic therapy, multiple other mechanisms have been described as predisposing to epidural hematoma formation. These are related to either epidural venous and arterial bleeding, bleeding from arterial venous malformations, or anatomic abnormalities of the vertebral column resulting in engorgement of the posterior internal vertebral venous plexus $(31,36,37,39,40)$. Other risk factors include anatomic abnormalities of the vertebral column, older age, intrinsic thrombocytopenia, platelet dysfunction, renal failure, technically difficult procedure or multiple attempts to perform epidural puncture, and coagulopathy related to hemophilia (28). Anatomically, the thoracic spinal cord is vulnerable to compression, more commonly compared to lumbar region, but less commonly compared to cervical spine. Other factors included fish oil as well as fluoxetine and ketorolac; however, it continues to be a major concern for interventional pain management physicians as the risk of thrombotic events may be higher with cessation of antithrombotic therapy. It is commonly believed that a single shot epidural injection is much safer than continuous catheterization.

\section{CONCLUSION}

Thoracic interlaminar epidural injections are performed infrequently in managing chronic thoracic pain with local anesthetic alone or with steroids. Anticoagulant therapy or antithrombotic therapy has been implicated as causative factors for formation of acute epidural hematoma after injection therapy; however, the majority of reports show that the development of acute epidural hematoma has been associated in patients after cessation of antiplatelet therapy. As this report illustrates and also other reports it is crucial to observe for unusual axial pain phenomenon. The pain after the procedure at the injection site appears to be different from ever experienced pain with previous injections for the loss of resistance with air only make complicate the closed space phenomena of cord compression. Finally, it is crucial to understand the risk benefit ratio and perform the procedures meticulously with appropriate precautions. In the case we present, timely recognition and management of the complication was key to good outcome.

\section{Acknowledgment}

The authors wish to thank Laurie Swick, BS for manuscript review, and Tonie M. Hatton and Diane E. Neihoff, transcriptionists, for their assistance in preparation of this manuscript. We would like to thank the editorial board of Pain Physician for review and criticism in improving the manuscript.

\section{Conflict of Interest}

Dr. Manchikanti has provided limited consulting services to Semnur Pharmaceuticals, Incorporated, which is developing nonparticulate steroids.

Dr. Benyamin is a consultant and lecturer for Boston Scientific and Kimberly Clark.

Dr. Hirsch is a consultant for Medtronic. 


\section{REFERENCES}

1. Manchikanti L, Pampati V, Hirsch JA. Utilization of interventional techniques in managing chronic pain in Medicare population from 2000 to 2014: An analysis of patterns of utilization. Pain Physician 2016; 19:E531-E546.

2. Manchikanti L, Pampati V, Hirsch JA. Retrospective cohort study of usage patterns of epidural injections for spinal pain in the US fee-for-service Medicare population from 2000 to 2014. BMJ Open 2016; 6:e013042.

3. Manchikanti L, Malla Y, Wargo BW, Cash KA, Pampati V, Fellows B. A prospective evaluation of complications of 10,000 fluoroscopically directed epidural injections. Pain Physician 2012; 15:131-140.

4. Manchikanti L, Cash KA, McManus CD, Pampati V, Benyamin RM. A preliminary report of a randomized double-blind, active controlled trial of fluoroscopic thoracic interlaminar epidural injections in managing chronic thoracic pain. Pain Physician 2010; 13:E357-E369.

5. Kaye AD, Manchikanti L, Abdi S, Atluri S, Bakshi S, Benyamin R, Boswell MV, Buenaventura R, Candido KD, Cordner HJ, Datta S, Doulatram G, Gharibo CG, Grami V, Gupta S, Jha S, Kaplan ED, Malla Y, Mann DP, Nampiaparampil DE, Racz G, Raj P, Rana MV, Sharma ML, Singh V, Soin A, Staats PS, Vallejo R, Wargo BW, Hirsch JA. Efficacy of epidural injections in managing chronic spinal pain: A best evidence synthesis. Pain Physician 2015; 18:E939-E1004.

6. Manchikanti L, Nampiaparampil DE, Manchikanti KN, Falco FJE, Singh V, Benyamin RM, Kaye AD, Sehgal N, Soin A, Simopoulos TT, Bakshi S, Gharibo CG, Gilligan CJ, Hirsch JA. Comparison of the efficacy of saline, local anesthetics, and steroids in epidural and facet joint injections for the management of spinal pain: A systematic review of randomized controlled trials. Surg Neurol Int 2015; 6:S194-S235.

7. Loomba V, Kaveeshvar H, Dwivedi S. Paraplegia after thoracic epidural steroid injection. A Case Rep 2016; 7:118-121.

8. Snarr J. Risk, benefits and complications of epidural steroid injections: A case report. AANA J 2007; 75:183-188.

9. Okitsu K, Iritakenishi T, Iwasaki M, Imada T, Fujino Y. Risk of hematoma in patients with a bleeding risk undergoing cardiovascular surgery with a paravertebral catheter. J Cardiothorac Vasc Anesth 2016 [Epub ahead of print].

10. Kupersztych-Hagege E, Dubuisson E, Szekely B, Michel-Cherqui M, François Dreyfus J, Fischler M, Le Guen M. Epidural hematoma and abscess related to thoracic epidural analgesia: $A$ single-center study of 2,907 patients who underwent lung surgery. J Cardiothorac Vasc Anesth 2016 [Epub ahead of print].

11. Raj R, Seppälä M, Siironen J. Spontaneous spinal epidural hematoma: A surgical case series of ten patients. World Neurosurg 2016; 93:55-59.

12. Liu WH, Hsieh CT, Chiang YH, Chen GJ. Spontaneous spinal epidural hematoma of thoracic spine: A rare case report and review of literature. Am J Emerg Med 2008; 26:384.e1-e2.

13. Cai HX, Liu C, Zhang JF, Wan SL, Uchida K, Fan SW. Spontaneous epidural hematoma of thoracic spine presenting as Brown-Séquard syndrome: Report of a case with review of the literature. J Spinal Cord Med 2011; 34:432-436.

14. Aycan A, Ozdemir S, Arslan H, Gonullu E, Bozkina C. Idiopathic thoracic spontaneous spinal epidural hematoma. Case Rep Surg 2016; 2016:5430708.

15. Elder BD, Ishida W, lyer R, Witham TF. Rapid resolution of large spontaneous thoracic epidural hematoma without surgical intervention. Spine J 2016; 16:e613-e614.

16. Lee SB, Lee TG, Yoo DS, Huh PW, Cho KS. Thoracic spinal cord epidural hematoma after extracorporeal shock wave lithotripsy. J Neurosurg Spine 2012; 16:127-129.

17. Lee TH, Chen DF, Lee TC, Lee HL, Lu CH. Acute thoracic epidural hematoma following spinal manipulative therapy: Case report and review of the literature. Clin Neurol Neurosurg 2011; 113:575-577.

18. Rudd JW, Williams A, Sudhakar N, Shivane A. Thoraco-lumbar spontaneous ligamentum flavum haematoma. $\mathrm{Br} \mathrm{J}$ Neurosurg 2013; 27:543-544.

19. Ghaly RF, Lissounov A, Candido KD, Knezevic NN. Are there guidelines for implantable spinal cord stimulator therapy in patients using chronic anticoagulation therapy? - A review of decision-making in the high-risk patient. Surg Neurol Int 2016; 7:33.

20. Buvanendran A, Young AC. Spinal epidural hematoma after spinal cord stimulator trial lead placement in a patient taking aspirin. Reg Anesth Pain Med 2014; 39:70-72.

21. Kumar K, Caraway DL, Rizvi S, Bishop S. Current challenges in spinal cord stimulation. Neuromodulation 2014; 17:22-35.

22. Levy R, Henderson J, Slavin K, Simpson BA, Barolat G, Shipley $J$, North R. Incidence and avoidance of neurologic complications with paddle type spinal cord stimulation leads. Neuromodulation 2011; 14:412-422.

23. Serrano BM, Cuenca EC, Higuera EG, Espla AF, Diaz EG, Ares JA. Anticoagulation and interventional pain management. Tech Reg Anesth Pain Manag 2014; 18:58-64.

24. Moufarrij NA. Epidural hematomas after the implantation of thoracic paddle spinal cord stimulators. J Neurosurg 2016; 125:982-985.

25. Xu R, Bydon M, Gokaslan ZL, Wolinsky JP, Witham TF, Bydon A. Epidural steroid injection resulting in epidural hematoma in a patient despite strict adherence to anticoagulation guidelines. $J$ Neurosurg Spine 2009; 11:358-364.

26. Benyamin RM, Vallejo R, Wang V, Kumar N, Cedeño DL, Tamrazi $A$. Acute epidural hematoma formation in cervical spine after interlaminar epidural steroid injection despite discontinuation of Clopidogrel. Reg Anesth Pain Med 2016; 41:398-401.

27. Jenkie EJ, Benyamin RM, Manchikanti L. Fish oil as a potential contributor to epidural hematoma following cervical epidural steroid injection: A case report and focused literature review. IPM Reports 2017; 1:19-26.

28. Manchikanti L, Malla Y, Benyamin RM, Hirsch JA. Prevalence of epidural hematoma following cervical epidural injections in interventional pain management settings: Literature review with two case reports. IPM Reports 2017; 1:11-17.

29. Swicegood JR, Manchikanti L, Benyamin RM, Hirsch JA. Two cases of acute epidural hematoma formation after cervical interlaminar epidural steroid injections. IPM Reports 2017; 1:27-32.

30. Terada Y, Toda H, Hashikata H, Yamamoto Y, Nagai Y, Yoshimoto N, Goto M, Nishida N, Iwasaki K. Treatment of non-traumatic spinal epidural hematoma: A report of five cases and a systematic review of the literature. No Shinkei Geka 2016; 44:669-677.

31. Chien GC, McCormick Z, Araujo M, Candido KD. The potential contributing effect of ketorolac and fluoxetine to a spinal epidural hematoma following a cervical interlaminar epidural steroid injection: A case report and narrative review. Pain Physician 2014; 


\section{7:E385-E395.}

32. Mozaffarian D, Benjamin EJ, Go AS, Arnett DK, Blaha MJ, Cushman M, Das SR, de Ferranti S, Després JP, Fullerton HJ, Howard VJ, Huffman MD, Isasi CR, Jiménez MC, Judd SE, Kissela BM, Lichtman JH, Lisabeth LD, Liu S, Mackey RH, Magid DJ, McGuire DK, Mohler ER 3rd, Moy CS, Muntner P, Mussolino ME, Nasir K, Neumar RW, Nichol G, Palaniappan L, Pandey DK, Reeves MJ, Rodriguez CJ, Rosamond W, Sorlie PD, Stein J, Towfighi A, Turan TN, Virani SS, Woo D, Yeh RW, Turner MB; American Heart Association Statistics Committee and Stroke Statistics Subcommittee. Heart Disease and Stroke Statistics-2016 Update: A report from the American Heart Association. Circulation 2016; 133:e38-e360.

33. Manchikanti L, Benyamin RM, Swicegood JR, Falco FJE, Datta S, Pampati V, Fellows B, Hirsch JA. Assessment of practice patterns of perioperative management of antiplatelet and anticoagulant therapy in interventional pain management. Pain Physician 2012; 15:E955-E968.

34. Manchikanti L, Malla Y, Wargo BW, Cash KA, McManus CD, Damron KS, Jackson SD, Pampati V, Fellows B. A prospective evaluation of bleeding risk of interventional techniques in chronic pain. Pain Physician 2011; 14:317-329.

35. Endres S, Shufelt A, Bogduk N. The risks of continuing or discontinuing anticoagulants for patients undergoing common interventional pain procedures. Pain Med 2016 Jun 12. [Epub ahead of print]

36. Norouze S, Benzon HT, Provenzano DA, Buvanendran A, De Andres J, Deer TR, Rauck R, Huntoon MA. Interventional spine and pain procedures in patients on antiplatelet and anticoagulant medications: Guidelines from the American Society of Re- gional Anesthesia and Pain Medicine, the European Society of Regional Anaesthesia and Pain Therapy, the American Academy of Pain Medicine, the International Neuromodulation Society, the North American Neuromodulation Society, and the World Institute of Pain. Reg Anesth Pain Med 2015; 40:182-212.

37. Manchikanti L, Falco FJE, Benyamin RM, Caraway DL, Kaye AD, Helm II S, Wargo BW, Hansen H, Parr AT, Singh V, Swicegood JR, Smith HS, Schultz DM, Malla Y, Hirsch JA. Assessment of bleeding risk of interventional techniques: A best evidence synthesis of practice patterns and perioperative management of anticoagulant and antithrombotic therapy. Pain Physician 2013; 16:SE261-SE318.

38. Manchikanti L, Abdi S, Atluri S, Benyamin RM, Boswell MV, Buenaventura RM, Bryce DA, Burks PA, Caraway DL, Calodney AK, Cash KA, Christo PJ, Cohen SP, Colson J, Conn A, Cordner HJ, Coubarous S, Datta S, Deer TR, Diwan SA, Falco FJE, Fellows B, Geffert SC, Grider JS, Gupta S, Hameed H, Hameed M, Hansen H, Helm II S, Janata JW, Justiz R, Kaye AD, Lee M, Manchikanti KN, McManus CD, Onyewu O, Parr AT, Patel VB, Racz GB, Sehgal N, Sharma M, Simopoulos TT, Singh V, Smith HS, Snook LT, Swicegood J, Vallejo R, Ward SP, Wargo BW, Zhu J, Hirsch JA. An update of comprehensive evidence-based guidelines for interventional techniques of chronic spinal pain: Part II: Guidance and recommendations. Pain Physician 2013; 16:S49S283.

39. Groen RJ, Ponssen H. The spontaneous spinal epidural hematoma. A study of the etiology. J Neurol Sci 1990; 98:121-138.

40. Lim SH, Hong BY, Cho YR, Kim HS, Lee JI, Kim HW, Ko YJ. Relapsed spontaneous spinal epidural hematoma associated with aspirin and clopidogrel. Neurol Sci 2011; 32:687-689. 